\title{
ВІДТВОРЮВАЛЬНІ ЯКОСТІ СВИНОМАТОК МАТЕРИНСЬКИХ ТА БАТЬКІВСЬКОӦ ЛІНІЙ
}

Повод Микола Григорович доктор сільськогосподарських наук, професор Сумський національний аграрний університет ORCID ID: 0000-0001-9272-9672/ W-1565-2018

Email: nic.pov@ukr.net

Михалко Олександр Григорович аспірант спец. 204 ТВППТ Сумський національний аграрний університет ORCID ID: 0000-0002-0736-2296/ G-2305-2018 Email: snau.cz@ukr.net

Кремезь Микола Іванович аспірант спец. 204 ТВППТ

Сумський національний аграрний університет ORCID ID: 0000-0002-1110-4986 Email: nikolajkremez@gmail.com

Метою статті було дослідити залежність відтворювальної продуктивності свиноматок за розведення від материнських і батьківських генотипів. Для проведення досліджень відтворювальних якостей свиноматок материнських та батьківського генотипів було проведено аналіз продуктивності свиноматок материнських (велика біла та ландрас) $i$ батьківської (синтетичної лінії Махgro) ірландської селекції. за загальною кількістю народжених поросят свиноматки великої білої породи вірогідно на 1,29 (p< 0,01) та 6,23 (p< 0,001) голів переважали своїх аналогів з дослідних груп, що говорить про великий потенціал багатоплідності иієї материнської лінії. Свиноматки іншої материнської породи також переважали на 4,94 (p< 0,001) голови своїх ровесниць батьківської синтетичної лінії. В наших дослідженнях у свиноматок материнських генотипів, через їх високу багатоплідність збереженість поросят до відлучення на 28 добу їх життя виявилась на 22,85 та 17,70\% (p< 0,001) гіршою в порівнянні з тваринами батьківської синтетичної лінії. Найгіршою збереженість виявилась у свиноматок контрольної групи, які за цим показником поступались 4,85\% своїм ровесницям породи ландрас $(p<0,05)$. За показником маси гнізда поросят при відлученні свиноматки породи ландрас переважали за цим показником на 7,12 кट (р< 0,01) своїх аналогів великої білої породи та на 4,24 кट (p< 0,05) ровесниць батьківської синтетичної лінії Maxgro. В свою чергу не встановлено суттєвих відмінностей за масою гнізда поросят при відлучені у свиноматок великої білої породи та синтетичної лінії Махgro. За комплексом відтворювальних ознак, які визначали за допомогою розрахунку селекційного індексу відтворювальних якостей свиноматок (СІВЯС), найкращими виявились свиноматки великої білої породи 97,72 бали. Всього на 0,84 бали їм поступались тварини іншої материнської лінії в породі ландрас. Водночас свиноматки обох материнських генотипів перевершували аналогів з батьківської синтетичної лінії Махgго на 31,64 та 29,66 бали. лінії

Ключові слова: відтворювальні якості, збереженість, багатоплідність, маса гнізда, материнські лінії, батьківські

DOI: https://doi.org/10.32845/bsnau.Ivst.2021.4.22

Свинарство вважається одним із головних джерел виробництва м'яса. У більшості країн світу зараз вирощується понад 100 видів та порід свиней. Сьогодні свинина продовжує відігравати важливу роль в раціоні людини як одного з головних джерел енергії та високоцінного білка тваринного походження. Свинарство в Україні відіграє істотну роль у формуванні продовольчої безпеки населення країни, оскільки у загальному попиті на частку споживання припадає понад $40 \%$ свинини. [1, 2, 5].

В сучасних умовах глобалізації продовольчого ринку, 3 метою підвищення конкурентності, виробники свинини використовують найпередовіші досягнення в цій галузі, одним з яких є впровадження передових технологій в розведенні свиней,а саме, використання внутрішньовидової гібридизації свиней. В поточному визначенні терміну внутрішньовидової гібридизації, як зазначають вітчизняні дослідники [4] - € поєднання відселекціонованих за окремими ознаками батьківських і материнських генотипів для отримання високопродуктивних товарних гібридів. Також внутрішньовидова гібридизація може полегшити інвазії, підвищити резистентність до хвороб, тому що гібриди проявляють вище фенотипове середнє значення і дисперсію, ніж їхні батьки [15]. Гібридизація може забезпечити необхідну генетичну мінливість для адаптивної еволюції всередині виду [14]. У свинарстві, гібридами прийнято називати нащадків одержаних від поєднання кнурів і свиноматок спеціально відселекціонованих порід, типів і ліній як чистопородних, так і синтетичних, які перевірені на комбінаційну здатність [12]. Гібридизація, як стверджують закордонні автори $[16,20] \epsilon$ новим, вищим етапом схрещування спеціально відселекціонованих материнських і батьківських фоорм, для яких характерна стійка передача нащадкам відтворювальних, відгодівельних і забійних якостей, що не властиво породам, щодо яких проводиться комплексна селекція. 
Загальновідомо, що гетерозис виникає в результаті схрещування, покращуючи продуктивність свиней. Гени успадковуються парами, по одному від кожного з батьків. Гетерозис збільшує кількість різних пар алелей і збільшує гетерозиготність, що призводить до пригнічення небажаних рецесивних алелей від одного з батьків домінантними алелями від другого з батьків. Переваги гібридизації за рахунок використання гетерозису добре доведені науковими експериментами і комерційними записами [19]. Гетерозис складається 3 трьох компонентів: індивідуального (відбувається при схрещуванні потомства), материнського (при схрещуванні матері) і батьківського (при схрещуванні батька). Таким чином, при схрещуванні двох чистокровних порід буде отримано потомство з індивідуальним гетерозисом, яке покаже поліпшене виживання $[13,17,18]$.

Водночас, згідно останніх опублікованих праць [6] досягається високий ефект гетерозису i, як результат, відповідно істотне збільшення продуктивності тварин (на 10$17 \%$ ) і поліпшення якісних показників продукції. Так в результатах зарубіжних вчених вплив прямого гетерозису значно збільшив середньодобові прирости від народження до 14, 28 до 56 та від 70 до 154 днів [11]. Також доведено, що прямий гетерозис значно збільшував кількість сосків, вагу в період статевого дозрівання, втрату ваги в період лактації, розмір посліду і вагу при народженні. Тривалість вагітності в і вік статевого дозрівання в були значно зменшені прямим гетерозисом [8].

Хоча гетерозис або гібридна сила - це поліпшені показники потомства в порівнянні з середніми показниками їх батьків, однак, у міру збільшення однорідності генетичного пулу збільшується і можливість експресії небажаних генів. Це, в свою чергу, може привести до зниження продуктивності $[9,10,21]$. Свині нових спеціалізованих ліній відрізняються високою продуктивністю, обумовленою генетично. Але в той же час це є причиною високої чутливості до впливу несприятливих факторів зовнішнього середовища [2].

Тому останнім часом у свинарстві ведуться дослідження зі створення методами переважної селекції родинних форм (батьківських і материнських), підбір яких у межах породи забезпечує прояв гетерозисного ефекту за окремими ознаками продуктивності (за обмеженою кількістю ознак. При цьому батьківські форми селекціонують за скоростиглістю, оплатою корму, відгодівельними та м'ясними якостями, а материнські за - багатоплідністю, великоплідністю, молочністю, масою гнізда на час відлучення, збереженістю молодняку [5].

Таким чином, порівняльне вивчення відтворювальних якостей свиней за використання материнських і батьківської ліній є досить актуальним.

Метою роботи є дослідження відтворювальної продуктивності материнських і батьківських генотипів за промислової технології виробництва свинини.

Матеріали і методи досліджень. Для проведення досліджень відтворювальних якостей свиноматок материнських та батьківського генотипів було проведено аналіз продуктивності свиноматок материнських (велика біла та ландрас) і батьківської (синтетичної лінії «Максгро») ірландської селекції за 2018-2019 роки в умовах племінного репродуктору ТОВ «НВП «Глобинський свинокомплекс». В якості контролю були прийняті чистопородні свиноматки великої білої породи ірландського походження генетичної компанії Хермітаж Генетікс (I група). До другої групи ввійшли чистопородні їх аналоги породи ландрас тієї ж компанії. Третю групу склали свиноматки синтетичної лінії «Максгро» також селекційної компанії Хермітаж Генетікс. Свиноматок I групи, осіменяли спермою кнурів великої білої породи ірландської селекції. Свиноматок II груп осіменяли спермою кнурів породи ландрас тієї ж селекції. А тварин III дослідної групи спермою кнурів синтетичної лінії «Максгро» також ірландської селекції.

Утримання свиноматок всіх трьох груп було ідентичним в усі періоди репродуктивного циклу. Годівля також була повнораціонною, збалансованою комбікормами власного виробництва ідентичною для тварин усіх груп. В дослідженнях враховували наступні показники продуктивності: загальну кількість народжених поросят, багатоплідність, масу гнізда поросят при народженні, кількість, індивідуальну масу та масу гнізда поросят при відлучені.

Селекційний індекс відтворювальних якостей свиноматок (СІВЯС) визначали згідно методики О.М. Церенюка [7]:

$$
\text { CIBЯC }=6 \mathrm{X}_{1}+9,34\left(\frac{\mathrm{X}_{2}}{\mathrm{X}_{3}}\right),
$$

де CIBЯC - селекційний індекс відтворювальних якостей свиноматок; $\mathrm{X}_{1}$-багатоплідність, гол; $\mathrm{X}_{2}$-маса гнізда при відлученні, кг; $X_{3}$ - термін відлучення, діб; 6 та 9,34 - коефріцієнти.

Статистичну обробку даних експериментальних досліджень проводили методами математичної статистики на ПК 3 використанням програмного забезпечення Microsoft Excel. Результати вважали статистично достовірними за першого - $\mathrm{P}<0,05$ (1), другого - $\mathrm{P}<0,01$ (2) та третього $\mathrm{P}<0,001(3)$ порогів вірогідності.

Результати досліджень. Як видно з даних табл. 1 за загальною кількістю народжених поросят свиноматки великої білої породи (I контрольна група) вірогідно на 1,29 $(p<0,01)$ та 6,23 ( $<<0,001)$ голів переважали своїх аналогів 3 дослідних груп, що говорить про великий потенціал багатоплідності цієї материнської лінії. Свиноматки іншої материнської породи також переважали на 4,94 ( $<<0,001)$ голови своїх ровесниць батьківської синтетичної лінії, що на нашу думку $€$ результатом цілеспрямованої селекційної роботи при створення цих ліній.

За фактичною багатоплідністю також встановлена вірогідна $(p<0,001)$ перевага свиноматок материнських ліній над їх аналогами з батьківської на 4,85-5,0 голів. Водночас між тваринами обох материнських ліній суттєвих розбіжностей за цим показником не встановлено, а лише простежувалась тенденція до вищої на 0,15 голів багатоплідності у свиноматок великої білої породи.

За більшої кількості поросят в гнізді при народжені, закономірно знижується їх маса. Як видно з даних досліду великоплідність була найвищою в гніздах поросят свиноматок синтетичної лінії Maxgro. Поросята цієї групи були важчими за своїх аналогів з гнізд материнських ліній на 0,11та $0,13$ кг ( $p<0,001)$ відповідно. Тоді як різниця за великоплідністтю між тваринами великої білої та ландрас порід склала всього 0,02кг $(p<0,05)$ 
Відтворювальні якості свиноматок материнських та батьківського генотипу $\mathrm{M} \pm \mathrm{m}$

\begin{tabular}{|c|c|c|c|}
\hline Показник & 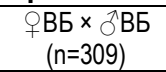 & 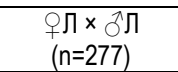 & $\begin{array}{c}\mathrm{OMr} \times \widehat{\mathrm{M}} \mathrm{Mr} \\
(\mathrm{n}=182)\end{array}$ \\
\hline Група піддослідних тварин & I & $\|$ & III \\
\hline Всього народилося поросят, гол. & $18,27 \pm 0,302$ & $16,98 \pm 0,257^{* *}$ & $12,04 \pm 0,284^{\star \star \star}$ \\
\hline Багатоплідність, гол. & $15,89 \pm 0,303$ & $15,74 \pm 0,258$ & $10,89 \pm 0,251^{\star \star \star}$ \\
\hline Маса гнізда при народженні, кг & $20,97 \pm 0,363$ & $20,46 \pm 0,347$ & $15,44 \pm 0,256^{* \star \star}$ \\
\hline Великоплідність, кг & $1,32 \pm 0,006$ & $1,30 \pm 0,007^{*}$ & $1,43 \pm 0,007^{* * *}$ \\
\hline Маса поросяти при відлученні, кг & $7,12 \pm 0,072$ & $7,32 \pm 0,056^{*}$ & $8,16 \pm 0,042^{* * *}$ \\
\hline Кількість поросят при відлученні, гол. & $11,38 \pm 0,200$ & $12,05 \pm 0,134^{* *}$ & $10,29 \pm 0,236^{* * *}$ \\
\hline Збереженість поросят, \% & $71,64 \pm 1,915$ & $76,49 \pm 1,764$ & $94,49 \pm 1,142^{* * *}$ \\
\hline Маса гнізда поросят при відлучені, кг & $81,02 \pm 1,363$ & $88,21 \pm 1,712^{* *}$ & $83,97 \pm 1,913^{*}$ \\
\hline СІВЯС, балів & 97,72 & 96,88 & 68,06 \\
\hline
\end{tabular}

Оскільки маса гнізда поросят при народжені залежить від їх кількості в гнізді та великоплідності, то за рахунок суттєво більшої багатоплідності у свиноматок материнських ліній вона виявилась на 5,53 та 5,02 кг ( $p<0,001)$ вищою порівняно з тваринами батьківської синтетичної лінії. Між тваринами материнських ліній суттєвих відмінностей за масою гнізда поросят при народжені не встановлено. Збереженість поросят в гнізді до відлучення також суттєвою мірою залежить від багатоплідності та материнських якостей свиноматок. В наших дослідженнях у свиноматок материнських генотипів, через їх високу багатоплідність збереженість поросят до відлучення на 28 добу їх життя виявилась на 22,85 та $17,70 \%$ (p< 0,001) гіршою в порівнянні з тваринами батьківської синтетичної лінії. Найгіршою збереженість виявилась у свиноматок контрольної групи, які за цим показником поступались 4,85\% своїм ровесницям породи ландрас ( $p<$ $0,05)$.

Не дивлячись на значно кращу збереженість поросят у свиноматок синтетичної батьківської лінії Maxgro, їх кількість до відлучення виявилась вірогідно меншою в порівнянні 3 обома материнськими лініями. Так, тваринам великої білої вони поступались за цією ознакою на 1,09 голови ( $p<$ 0,001), тоді як ровесницям породи ландрас - на 1,76 голови ( $p<0,001)$. Серед материнських ліній більшу на 0,67 голови ( $<<0,01)$ кількість поросят при відлучені мали свиноматки другої дослідної групи.

Найбільш вагомою ознакою є маса гнізда поросят при відлучені, яка акумулює в себе, як кількість поросят в гнізді, так і їх індивідуальну живу масу. Як витікає з табл. 1 найвищою вона виявилась у свиноматок породи ландрас, які переважали за цим показником на 7,12 кг ( $p<0,01)$ своїх аналогів великої білої породи та на 4,24 кг $(p<0,05)$ ровесниць батьківської синтетичної лінії Maxgro. В свою чергу не встановлено суттєвих відмінностей за масою гнізда поросят при відлучені у свиноматок великої білої породи та синтетичної лінії Maxgro.

За комплексом відтворювальних ознак, які визначали за допомогою розрахунку селекційного індексу відтворювальних якостей свиноматок (СІВЯС), найкращими виявились свиноматки великої білої породи 97,72 бали. Всього на 0,84 бали їм поступались тварини іншої материнської лінії в породі ландрас. Водночас свиноматки обох материнських генотипів перевершували аналогів з батьківської синтетичної лінії Maxgro на 31,64 та 29,66 бали.

Висновок. Свиноматки материнських ліній великої білої та ландрас порід мали вищу багатоплідність, масу гнізда поросят при народжені, кількість поросят при відлучені і переважали тварин синтетичної лінії Maxgro на 31,64 та 29,66 бали за комплесним показником селекційного індексу відтворювальних якостей свиноматок (СІВЯС).

Свиноматки батьківської лінії Maxgro мали вищу великоплідність, індивідуальну масу поросят при відлучені та збереженість поросят до відлучення.

За масою гнізда поросят при відлучені чіткої закономірності в залежності цієї ознаки від генотипу свиноматок не встановлено.

\section{Список використаної літератури:}

1. Зиновчук В. В., Климюк Л. Н. Проблемы и перспективы формирования рыночной инфраструктуры в регионе. Региональные аспекты аграрных преобразований. ІАМО, 2003. Вип. 17, С. 177-198.

2. Михалко О. Г. Сучасний стан та шляхи розвитку свинарства в світі та Україні. Вісник Сумського національного аграрного університету. Серія "Тваринництво", 2021, Вип. 3, С. 60-77.

3. Михалко О. Г., Повод М. Г., Андрійчук В. Ф., Вплив методів розведення та віку свиноматок данської селекції на їх продуктивність. «НТБ ІТ НААН», 2021, №125, С. 161-179.

4. Никитченко И.Н., Никитенко Р. Н., Горин В. В. Программа гибридизации в свиноводстве Белоруссии на основе селекционно-гибридных центров. Повышение эффективности свиноводства. М. Агроиздат, 1991, С. 19-28.

5. Оглобля В. В., Повод М. Г. Відтворювальні якості свиноматок ірландського походження за чистопородного розведення та схрещування в умовах промислового комплексу. Вісник Сумського національного аграрного університету. Серія "Тваринництво", 2020, Вип. 1(40), С. 103-107.

6. Церенюк О. М. Гетерозис у свинарстві. Сучасне тваринництво. [Електроний ресурс]. - Режим доступу: http://agrobusiness.com.ua/agro/suchasne-tvarynnytstvo/item/8035-heterozys-u-svynarstvi.html (дата звернення 30.09.2021)

7. Церенюк О. М., Хватов А. І., Стрижак Т. А. Оцінка ефективності індексів материнської продуктивності свиней. Сучасні проблеми селекції, розведення та гігієни тварин. 3б. наук. праць Вінницького НАУ, 2010, Вип. 3(42), С. $73-77$.

8. Baas, T. J., Christian, L. L. and Rothschild, M. F., 1992. Heterosis and recombination effects in Hampshire and Landrace swine: I. Maternal traits. J Anim Sci., issue 70(1), pp. 89-98. https://doi.org/10.2527/1992.70189x. PMID: 1582925. 
9. Bereskin, B., Shelby, C. E., Rowe, K. E., Urban, W. E., Blunn, C. T., Chapman, A. B., Garwood, V. A., Hazel, L. N., Lasley, J. F., McCarty, J. W. and Whatley, J. A., 1968. Inbreeding and swine productivity traits. J. Anim W.T. Sci., issue. 27 , p. 339.

10. Buchanan, D. S., 2006. Inbreeding in swine. Pork Information Gateway Factsheet 06-01-06 https://www.education.gov.gy/web2/index.php/students-resources/secondary-school-resources/grade11/grade11-worksheets/grade11-worksheets-agriculture-science/2268-grade-11-agriculture-science-week-5-lesson-1/file

11. Cassady, J. P, Young, L. D. and Leymaster, K. A., 2002. Heterosis and recombination effects on pig growth and carcass traits. J Anim Sci., issue 80(9), pp. 286-302.

12. Cobb, E. H., 1958. Comparative performance of purebred and crossbred swine on Pennsylvania farms. Thesis of PhD dissertation. lowa,

1958. https://lib.dr.iastate.edu/cgi/viewcontent.cgi?referer=https://www.google.com/\&httpsredir=1\&article=3246\&context=rtd

13. Das, A., Mukesh, C., Pardeep, K., Chikkappa, K., Yathish, K. R., Ramesh, K., Alla, S., Santosh, K., and Sujay, R., 2021. Heterosis in Genomic Era: Advances in the Molecular Understanding and Techniques for Rapid Exploitation. Critical Reviews in Plant Sciences, issue 40, pp. 218-242. https://doi.org/10.1080/07352689.2021.1923185

14. Erickson, D. L. and Fenster, C. B., 2006. Intraspecific hybridization and the recovery of fitness in the native legume chamaecrista fasciculata. Evolution, issue 60(2), pp. 225-233. https://doi.org/10.1554/05-020.1

15. Evin, A., Dobney, K. and Schafberg, R., 2015. Phenotype and animal domestication: A study of dental variation between domestic, wild, captive, hybrid and insular. Sus scrofa . BMC Evol Biol., issue15, p. 6. https://doi.org/10.1186/s12862-014-0269-x

16. Hopler, E., 1980. Das osterreichische Hybrid. Schwein. Prakt. Land, techu., issue 1, pp. 10-12.

17. Iversen, M. W., Nordbø, $\varnothing$., Gjerlaug-Enger, E., 2019. Effects of heterozygosity on performance of purebred and crossbred pigs. Genet Sel Evol., issue 51, p. 8 https://doi.org/10.1186/s12711-019-0450-1

18. Li, M. and Wang, L., 2016. Some Novel Insights into the Biological Heterozygous Effects. Journal of Veterinary Science \& Technology, issue 7, https://doi.org/10.4172/2157-7579.1000298

19. Liu, Z., Deng, Y., Li, Q., Liu, B., Xia, Y., Du, Y. and He, N., 2012. Research of the incubation and hybridization instrument with vibration for nanoparticles. J Nanosci Nanotechnol., issue 12(11), pp. 48-52. https://doi.org/10.1166/jnn.2012.6623. PMID: 23421229.

20. Shull, G. H., 1981. Hybridization methods in corn breeding. Amer. Breeding Magazine, issue 1., pp. 98-107.

21. Sierk, C. F. and Winters, L. M., A Study of Heterosis in Swine, Journal of Animal Science, Vol. 10, issue 1, pp. 104-111. https://doi.org/10.2527/jas1951.101104x

\section{References:}

1. Zinovchuk, V. V. and Klimyuk, L. N., 2003. Problemy i perspektivy formirovaniya rynochnoy infrastruktury v regione [Problems and prospects of the formation of market infrastructure in the region]. Regionalnye aspekty agrarnykh preobrazovaniy. IAMO, issue 17, pp. 177-198.

2. Mykhalko, O. H., 2021. Suchasnyi stan ta shliakhy rozvytku svynarstva v sviti ta Ukraini [Current state and ways of pig breeding development in the world and Ukraine]. Visnyk Sumskoho natsionalnoho ahrarnoho universytetu. Seriia "Tvarynnytstvo", issue. 3, pp. 60-77.

3. Mykhalko, O. H., Povod, M. H. and Andriichuk, V. F., 2021. Vplyv metodiv rozvedennia ta viku svynomatok danskoi selektsii na yikh produktyvnist [Influence of breeding methods and age of Danish sows on their productivity]. NTB IT NAAN, issue 125, pp. 161-179.

4. Nikitchenko, I. N., Nikitenko, R. N. and Gorin, V. V., 1991. Programma gibridizatsii v svinovodstve Belorussii na osnove selektsionno-gibridnykh tsentrov. Povysheniye effektivnosti svinovodstva [Hybridization program in pig breeding in Belarus based on hybrid breeding centers. Improving the efficiency of pig breeding]. Moscow. Agroizdat.

5. Ohloblia, V. V. and Povod, M. H., 2020. Vidtvoriuvalni yakosti svynomatok irlandskoho pokhodzhennia za chystoporodnoho rozvedennia ta skhreshchuvannia v umovakh promyslovoho kompleksu [Reproductive qualities of sows of Irish origin at purebred breeding and crossing in the conditions of an industrial complex]. Visnyk Sumskoho natsionalnoho ahrarnoho universytetu. Seriia "Tvarynnytstvo", issue. 1(40), pp. 103-107.

6. Tsereniuk, O. M., Heterozys u svynarstvi. Suchasne tvarynnytstvo. [Elektronyi resurs]. - Rezhym dostupu: http://agrobusiness.com.ua/agro/suchasne-tvarynnytstvo/item/8035-heterozys-u-svynarstvi.htm (data zvernennia 30.09.2021).

7.Tsereniuk, O. M., Khvatov, A. I. and Stryzhak, T. A., 2010. Otsinka efektyvnosti indeksiv materynskoi produktyvnosti svynei [Evaluation of the performance of pigs' maternal productivity indices]. Suchasni problemy selektsii, rozvedennia ta hihiieny tvaryn. Zbirniuk. naukovyh prats Vinnytskoho NAU, issue 3(42), pp. $73-77$.

8. Baas, T. J., Christian, L. L. and Rothschild, M. F., 1992. Heterosis and recombination effects in Hampshire and Landrace swine: I. Maternal traits. J Anim Sci., issue 70(1), pp. 89-98. https://doi.org/10.2527/1992.70189x. PMID: 1582925.

9. Bereskin, B., Shelby, C. E., Rowe, K. E., Urban, W. E., Blunn, C. T., Chapman, A. B., Garwood, V. A., Hazel, L. N., Lasley, J. F., McCarty, J. W. and Whatley, J. A., 1968. Inbreeding and swine productivity traits. J. Anim W.T. Sci., issue. 27 , p. 339.

10. Buchanan, D. S., 2006. Inbreeding in swine. Pork Information Gateway Factsheet 06-01-06 https://www.education.gov.gy/web2/index.php/students-resources/secondary-school-resources/grade11/grade11-worksheets/grade11-worksheets-agriculture-science/2268-grade-11-agriculture-science-week-5-lesson-1/file

11. Cassady, J. P, Young, L. D. and Leymaster, K. A., 2002. Heterosis and recombination effects on pig growth and carcass traits. J Anim Sci., issue 80(9), pp. 286-302.

12. Cobb, E. H., 1958. Comparative performance of purebred and crossbred swine on Pennsylvania farms. Thesis of PhD dissertation. lowa,

1958. 
https://lib.dr.iastate.edu/cgi/viewcontent.cgi?referer=https://www.google.com/\&httpsredir=1\&article=3246\&context=rtd

13. Das, A., Mukesh, C., Pardeep, K., Chikkappa, K., Yathish, K. R., Ramesh, K., Alla, S., Santosh, K., and Sujay, R., 2021. Heterosis in Genomic Era: Advances in the Molecular Understanding and Techniques for Rapid Exploitation. Critical Reviews in Plant Sciences, issue 40, pp. 218-242. https://doi.org/10.1080/07352689.2021.1923185

14. Erickson, D. L. and Fenster, C. B., 2006. Intraspecific hybridization and the recovery of fitness in the native legume chamaecrista fasciculata. Evolution, issue 60(2), pp. 225-233. https://doi.org/10.1554/05-020.1

15. Evin, A., Dobney, K. and Schafberg, R., 2015. Phenotype and animal domestication: A study of dental variation between domestic, wild, captive, hybrid and insular. Sus scrofa . BMC Evol Biol., issue15, p. 6. https://doi.org/10.1186/s12862-014-0269-x

16. Hopler, E., 1980. Das osterreichische Hybrid. Schwein. Prakt. Land, techu., issue 1, pp. 10-12.

17. Iversen, M. W., Nordbø, Ø., Gjerlaug-Enger, E., 2019. Effects of heterozygosity on performance of purebred and crossbred pigs. Genet Sel Evol., issue 51, p. 8 https://doi.org/10.1186/s12711-019-0450-1

18. Li, M. and Wang, L., 2016. Some Novel Insights into the Biological Heterozygous Effects. Journal of Veterinary Science \& Technology, issue 7, https://doi.org/10.4172/2157-7579.1000298

19. Liu, Z., Deng, Y., Li, Q., Liu, B., Xia, Y., Du, Y. and He, N., 2012. Research of the incubation and hybridization instrument with vibration for nanoparticles. J Nanosci Nanotechnol., issue 12(11), pp. 48-52. https://doi.org/10.1166/jnn.2012.6623. PMID: 23421229.

20. Shull, G. H., 1981. Hybridization methods in corn breeding. Amer. Breeding Magazine, issue 1., pp. 98-107.

21. Sierk, C. F. and Winters, L. M., A Study of Heterosis in Swine, Journal of Animal Science, Vol. 10, issue 1, pp. 104-111. https://doi.org/10.2527/jas1951.101104x

\section{Povod Mykola Hryhorovych, Doctor of Agricultural Sciences, Professor \\ Mykhalko Oleksandr Hryhorovych, graduate student \\ Kremez Mykola Ivnovych, graduate student \\ Sumy National Agrarian University (Sumy, Ukraine)}

Reproductive qualities of sows of maternal and paternal lines in the conditions of a breeding breeder

The aim of the article was to investigate the dependence of reproductive productivity of sows for breeding on maternal and paternal genotypes. To study the reproductive qualities of sows of maternal and paternal genotypes, the analysis of productivity of sows of maternal (large white and landrace) and paternal (synthetic line Maxgro) Irish selection was carried out in terms of the total number of piglets born, sows of large white breed probably outnumbered their analogues from the experimental groups by 1.29 ( $p$ $<0.01)$ and $6.23(p<0.001)$ heads, which indicates the great potential for multifertility of this maternal line. Sows of other maternal breeds also predominated by $4.94(p<0.001)$ heads of their peers of the paternal synthetic line. In our studies in sows of maternal genotypes, due to their high fertility, the survival of piglets before weaning on the 28th day of their life was 22.85 and $17.70 \%$ ( $p$ $<0.001)$ worse compared to animals of the paternal synthetic line. The worst survival was found in sows of the control group, which on this indicator were inferior to $4.85 \%$ of their peers of the Landrace breed $(p<0.05)$. In terms of nest weight of piglets at weaning, Landrace sows outperformed their large white breed counterparts by $7.12 \mathrm{~kg}(p<0.01)$ and $4.24 \mathrm{~kg}(p<0.05)$ by their peers of the parental Maxgro synthetic line. In turn, no significant differences were found in the nest weight of piglets when weaned from sows of large white breed and synthetic line Maxgro. According to the complex of reproductive traits, which were determined by calculating the selection index of reproductive qualities of sows (SIVYAS), the best were sows of large white breed 97.72 points. Animals of another maternal line in the Landrace breed were only 0.84 points behind them. At the same time, sows of both maternal genotypes were superior to the analogues from the paternal synthetic line Maxgro by 31.64 and 29.66 points.

Key words: reproductive qualities, safety, multiplicity, nest weight, maternal lines, paternal lines

Дата надходження до редакції: 30.09.2021 р. 